\title{
Nephrotoxicity Inhibition
}

National Cancer Institute

\section{Source}

National Cancer Institute. Nephrotoxicity Inhibition. NCI Thesaurus. Code C41590.

Nephrotoxicity Inhibition involves interference with, or restraint of, the activities of an agent, a biologic molecule or complex, or a cell having toxic or destructive action on kidney cells. 